\title{
Johtaisinko pedagogiikalla vai merkityksillä?
}

\section{Siv Their 1994. Pedagoginen johtaminen. Mermerus. Tampere: Tammer-Paino Oy. 184 sivua. \\ Timo Silen 1995. Organisaatiokulttuuri ja johtaminen. Kahden yrityksen kulttuurimuutosprosessin ja TOM-järjestelmän soveltamisen tarkastelu Helsingin Yliopisto. Helsinki: Valtiotieteellinen tiedekunta. 330 sivua.}

Siv Their ja Timo Silen kirjoittavat johtamisesta. Molemmat tekevät pesäeron kovaan, perinteiseen johtamisajatteluun.

Silen haluaa siirtää johtamista funktionaalisesta rationalismista enemmän ymmärtävään ja selittävään otteeseen. Hän yrittää löytää ratkaisun merkitysten johtamisesta. Siv Theirin lähtökohta on pedagoginen. Hän näkee johtajan roolin opettajana, joka ohjaa ja kouluttaa alaisiaan, panee samalla itsensä peliin ja oppii itsekin vuorovaikutuksen kautta.

Theirin kirja on 170-sivuinen, helppolukuiseksi tehty tiivistelmä hänen näkemyksistään ja tutkimustyöstään. Vaikeusasteeltaan se sopii melkein kenen tahansa luettavaksi. Silenin teeseistä kiinnostunut joutuu kaivautumaan läpi 300 sivuisen väitöskirjan laajoine teoria- ja empiirisine osineen. Harrastusta tarvitaan selvästi enemmän.

Helsingin yliopiston kasvatustieteen laitoksella toimiva Siv Their on kasvatustieteen tohtori. Timo Silen työskenteli konsulttina ja keräsi väitöskirjansa empiirisen aineiston kahdesta asiakasorganisaatiostaan. Salassapitomääräysten vuoksi organisaatiot on naamioitu tuntemattomiksi.

\section{Johtaja $=$ pedagogi?}

Siv Theirin näkemyksen mukaan hyvä johtaja on siis yhtä kuin hyvä opettaja. Pedagogista johtamista lähestytään lyhyen historiakatsauksen kautta. Their käy rivakasti läpi johtamisen suuntaukset ja esittelee pedagogisen johtamisen taustatekijöitä: siihen tarvittavan ihmiskäsityksen, näkemyksen tiedosta, pätevyyskäsityksen, arvot, motivaatiotakin sivutaan sekä johtajan roolin kokemista sekä johtamistapaa. Sitten tullaan itse asiaan: miten toimitaan silloin, kun johdetaan pedagogisen johtajan tavoin.

"Uutta johtajanroolia voidaan verrata opettajan tai pedagogin rooliin, johon sisältyy johtamisen ja auktoriteetin tunne, mutta jossa ilmaisumuodot, tekniikat ja metodit ovat toiset. Tässä roolissa johtaja jakaa tietojaan ja taitojaan tarkoituksenaan lisätä toisten osaamista runsaan kommunikaation avulla. johtaja on siten itse osallisena oppimisprosessissa. Johtaja on koko ajan yhteistyössä työntekijöidensä kanssa sekä heidän lähellään. Hän antaa nopeasti palautetta, seuraa koko ajan toimintaa, kuuntelee, puhuu, kyselee, ottaa huomioon, sopeutuu ja oppii ... mutta asettaa myös vaatimuksia ja ilmaisee, mitä odotuksia hänellä on eli hän toimii aivan kuten opettaja."

Loppupuolella kirjaa Their tarkastelee oppimista ja johtamista yksilön ja organisaation kannalta. Samaan lukuun sisältyy pikakurssi aikuispedagogiikasta ja jakso muutoksen johtamisesta. 


\section{Johtaja johtaa merkityksillä?}

Myös Timo Silen lähtee historiasta. Hän päätyy väittämään, etteivät aikaisemmat mallit enää riitä; ei tieteellisen liikkeenjohdon, ihmissuhteiden koulukunnan sen enempää kuin systeemirationaaliset painotuksetkaan. Hän niputtaa ne kaikki teknis-rationaalisiksi malleiksi.

Uusi lääke löytyy organisaatiokulttuurin käsitteestä ja varsinkin välineistä, jolla sitä muutetaan: "Pelkkä liikkeenjohdon tekninen ja rationaalinen korostaminen ei enää riittänyt, vaan nyt tarvittiin johtamisen kautta otetta yrityksen kulttuuriin uusien strategioiden ja visioiden joustavaksi soveltamiseksi" (s. 19).

Organisaatiokulttuurin määritelmässä Silen päätyy Edgar Scheiniin. Tosin Scheiniltakin puuttuu jotain: "Mutta hän (siis Schein) ei esitä selkeää teoreettista elementtiä esittämiensä asioiden yleiseksi viitekehykseksi. Tämä puuttuva elementti on merkitysten johtaminen..." (s. 59).

Ennen kuin Silen kertoo, mitä merkitysten johtaminen voisi olla periaatteessa, hän esittelee vielä johtamisen tutkimuksen neljä paradigmaa: funktionalistisen, tulkitsevan, radikaalin humanistisen, radikaalin strukturalistisen. Näistä Silenin mielestä toimivin voisi olla tulkitseva paradigma.

Merkitysten muodostumista ei Silenin mukaan voi tarkastella ilman fenomenalistisen lähestymistavan ymmärtämistä. Fenomenalismin eri painotuksista Silen päätyy Alfred Schutziin, jonka ajatuksia hän käyttää lähtökohtinaan. Silen johdattelee asiat teoriaosassa siihen, että fenomenologinen ote organisaatiokulttuurin ja johtamisen tutkimisessa täydentää teoreettisesti merkittävästi Scheinin näkökulmaa kulttuurin johtamiseen.

Mitä sitten on merkitysten johtaminen? Teoriaosassa Silen kuvaa sitä monessakin kohtaa, mutta jättää sen määrittelyn varsin väljäksi. Kohtuullisella yrittämisellä kirjasta löytyy joitakin kuvauksia:

"Esimerkiksi Smircichin ja Morganin (1982) mukaan merkitysten johtamisen keskeisenä haasteena on tällöin saada johdettavat keskittymään toivottaviin lopputuloksiin tulkitsemalla organisaation merkitysmaailmaa kielen, rituaalien, kertomusten ja symbolisen toiminnan kautta; näiden johtamisen työkalujen avulla johtaja voi suunnata huomion toivottaviin asioihin ja ottaa esiin ja muovata sellaisia tilanteiden merkityksiä, jotka edesauttavat johdettavan tilanteen hallintaa... (s. 89).

Silen siteeraa myös Juhani Nikkilää, joka mukaan fenomenologinen näkökulma korostaa tiedon suhteellisen laajaa prosessointia organisaation piirissä ja että merkitysten johtamisessa onkin korostettava johdon roolin rakenteellista puolta

- keiden intressit johtamisessa otetaan huomioon?

- millä perusteella johtamisen lojaliteetti määräytyy?

- millä tavalla johtaja turvaa lojaliteettinsa organisaation sisällä?

- millä tavoin johtamisessa käytettävä tieto ja tietoa koskevat merkitykset perustellaan oikeiksi ja tarkoituksenmukaisiksi? (s. 92)

Tämän jälkeen tutkimuksen teoreettinen tausta alkaa olla viritetty. Ei niin tieteellisesti suuntautuneelle lukijalle Silenin johdattelu on työlästä, mutta sivistävää.

\section{Teoriasta käytäntöön}

Silenin empiirinen osa käsittelee TQM:n eli kokonaisvaltaisen laatujohtamisen käyttöönottoa kahdessa asiakasorganisaatiossa. Päätutkimusmenetelminä olivat kyselytutkimukset, osallistuva havainnointi, dokumenttien analyysi ja haastattelut. 
Tulosten käsittely onkin varsin pitkälle haastattelu- ja havainnointiaineiston varassa. Sen avulla muodostuu varsin selvä kuva siitä, miksi toisessa esimerkkiyrityksessä uudistukset pystyttiin viemään läpi ja miksi toisessa ei tapahtunut paljon mitään; paitsi sen yhdessä alayksikössä.

Arkikielelle pelkistettynä jotkut Silenin tulokset ovat konkreettisia ja maanläheisiä: uudistukset eivät mene läpi, jollei johto todella muuta suhtautumistaan ja omia taustaoletuksiaan uudistuksen hengen (tässä TQM:n perusfilosofian ja ihmiskäsityksen) mukaiseksi ja jollei johto pyri toimimaan johdonmukaisesti tähän suuntaan.

Silen myös väittää, etteivät laatujohtaminen ja tulosjohtaminen istu yhteen. Tulosjohtaminen perustuu perinteiselle mallille, jossa ihmisten mukaan ottaminen ei ole aitoa, vaan näennäistä ja toiminta ja sen ohjaus perustuvat edelleen tiukan hierarkkiseen malliin.

\section{Uskovat ihmiseen}

Hyvää molemmissa kirjoissa on selkeä usko ihmisen kasvukykyyn ja johtamisen virittäminen sen varaan. Siv Theirin virittämä viitekehys on laaja: hän lähtee asiakkaista sekä yleensä toimintaympäristöstä tulevista muutossignaaleista ja tarjoaa ratkaisuksi johtamismallinsa. Theirin kirjan rakenne on hyvä: jokaisen kappaleen lopussa on kysymyksiä ja tehtäviä. Osittain tehtävät ovat vaativia, esimerkiksi neljännen luvun liitteenä oleva tehtävä 11 kävisi pienestä tentistä.

Sileninkin lähtökohta on kunnianhimoinen ja tiukka. Merkitysten johtajaksi ei voi vain ryhtyä, vaan se edellyttää omien taustaoletusten muuttamista ja itsensä peliin panemista. Itse asiassa sekä Theirin että Silenin viesti on sama: vierestä ei voi johtaa, on mentävä mukaan.

Vaikka Silenin kirja on kiusallisen raskaslukuinen eikä rakenteeltaan selvimpiä, pidän sitä näistä kahdesta huomattavasti antoisampana ja uskon hänen teesiensä elävän paremmin. Yhtenä syynä on se, että Silen ankkuroi väitteensä ja tutkimuksensa selkeään teoriataustaan. Varsinkin Silenin johdanto-osa on sivistävää lukemista ja tulosten läpikahlaaminen tuo mukanaan monta oivallusta.

Siv Theirin kirjan rasitteena on sen keittokirjamaisuus ja kielen viimeistelemättömyys. Vaikka esitys periaatteessa etenee loogisesti, jäivät esimerkiksi tiedon olemuksen ja informaatiojaksot irrallisiksi. Ja se, että Their panee johtajan ja opettajan roolin välille yhtäläisyysmerkin on rohkea teko. En vielä vakuuttunut, että tämä on perusteltua, vaikka näkemyksessä paljon hyvää onkin.

Ristiriitaista on myös se, että samaan aikaan kun Their korostaa johtajan yhteistoimintaa, hän kuitenkin lähtee yksittäisen johtajan yksin toimimisen näkökulmasta. Esimerkiksi nykyään vakavasti otettava tiimi- ja verkostoajattelu ei kirjassa näy. Ajatus alati läsnäolevasta johtajasta on perinteinen; eikö se lähesty jo vanhan hyvän työnjohtajan roolia, joka alati ohjaa ja paimentaa alaisiaan?

Nykymuodossaan Silenin ja Theirin kirjat kosiskelevat eri lukijakuntia. Theiriin tarttuu kiireisempikin johtaja tai kehittäjä ja lukaisee sen alkuillasta läpi. Silenin opus vaatii hieman harrastusta. josko siitä saisi kansanpainoksen?

Matti Hermunen 